\title{
Evaluation of PMA-qPCR methodology to detect and quantify viable Shiga toxin-producing Escherichia coli in beef burgers
}

\author{
María de los Ángeles Rey ${ }^{1,2}$ (i) | Mariana Cap ${ }^{1,2}$ (D) | Leonardo Cristian Favre ${ }^{1,2}$ | \\ Anabel Rodríguez Racca ${ }^{1,2}$ | María José Dus Santos ${ }^{3}$ | Sergio R. Vaudagna ${ }^{1,2}$ | \\ Marina Mozgovoj ${ }^{1,2}$
}

\author{
${ }^{1}$ Instituto Tecnología de Alimentos, Instituto \\ Nacional de Tecnología Agropecuaria (INTA), \\ Buenos Aires, Argentina \\ ${ }^{2}$ Instituto de Ciencia y Tecnología de \\ Sistemas Alimentarios Sustentables (UEDD \\ INTA-CONICET), Buenos Aires, Argentina \\ ${ }^{3}$ Instituto de Virología e Innovaciones \\ tecnológicas, Centro de Investigaciones en \\ Ciencias Veterinarias y Agronómicas, INTA- \\ CONICET, Buenos Aires, Argentina

\section{Correspondence} \\ María de los Ángeles Rey, Instituto \\ Tecnología de Alimentos, INTA, Nicolás \\ Repetto y de Los Reseros s/n (1686), \\ Hurlingham, Provincia de Buenos Aires, \\ Argentina. \\ Email: rey.angeles@inta.gob.ar

\section{Funding information} \\ This work was supported by MINCYT \\ PICT-2015-0291 and the research project \\ 2019-PE-E7-I147-001 from the National \\ Institute of Agriculture Technology (INTA).
}

\begin{abstract}
Propidium monoazide (PMA) is a selective nucleic acid intercalating dye that can be combined with real-time PCR (qPCR) in order to evaluate cell viability in food samples. The aim of the present work was to evaluate PMA-qPCR to detect and quantify viable STEC cells in beef burgers using st $x_{2}$ as target gene. First, it was determined that $100 \mu \mathrm{M}$ of PMA could inhibit qPCR signal from non-viable cells and had no influence on the amplification of different concentrations of viable cells. Then, it was shown that PMA efficiently distinguished between different log cfu of viable cells in presence of a high concentration of non-viable cells, both in culture and in beef burger homogenates. Finally, it was determined that PMA could distinguish between viable and non-viable cells within the same log cfu in beef burger homogenates. PMA-qPCR effectively detected and quantified viable STEC cells in culture and in beef burger homogenates.

Novelty impact statement: The main achievement of this work is that we demonstrate PMA-qPCR could not only detect, but also quantify viable STEC cells targeting stx2 gene, even in the presence of a high concentration of non-viable STEC cells in a complex matrix as beef burgers. This methodology can be used to assess effectiveness of antimicrobial treatments to reduce STEC contamination in meat products more rapidly and with less pathogenic residues than conventional methods.
\end{abstract}

\section{1 | INTRODUCTION}

Propidium monoazide combined with a real-time polymerase chain reaction (PMA real-time PCR), is one of the most promising methods to evaluate viable cells in food samples. The basic mechanism relies on the ability of PMA to penetrate compromised membranes of non-viable cells, given that when the cell membrane is intact, PMA is incapable to penetrate. A following photoactivation step converts the azido group of the PMA to a reactive nitrene radical which reacts with the double-stranded DNA and binds to it with high affinity (Taskin et al., 2011). This reaction inhibits PCR amplification of the modified DNA-targeted sequence (Nocker et al., 2006).

This method offers several advantages over traditional techniques. It can determine viable counts faster than plate counting. In addition, produces less waste, it is more specific and less time consuming. Moreover, some authors have demonstrated that it is able to detect viable but not cultivable cells (Banihashemi et al., 2012; Fu et al., 2020; Liu et al., 2018; Scariot et al., 2018; Taskin et al., 2011; Zhong \& Zhao, 2018). 
One of its potential uses is to assess the effectiveness of antimicrobial treatments against foodborne pathogens in different food matrixes (Laidlaw et al., 2019). In this context, some researchers have evaluated it for the detection of viable Escherichia coli 0157:H7 (Xing-Long et al., 2013).

Shiga toxin-producing Escherichia coli (STEC) includes all E. coli carrying the stx gene. This bacterium is a foodborne pathogen that has been frequently related to the consumption of contaminated ground beef and burgers (Centers for Disease Control and Prevention, 2019). STEC can cause bloody diarrhea, hemorrhagic colitis, and hemolytic uremic syndrome (HUS) (Guth et al., 2010). The most common serotype associated with human diseases worldwide, including Argentina, is O157:H7. The main virulence factor of STEC is the production of Shiga toxins 1 and 2 encoded by stx $x_{1}$ and $s t x_{2}$ genes, respectively.

The food matrixes in which PMA real-time PCR has been successfully applied for the detection of viable cells of E. coli O157:H7 were beef cuts, ground beef, and vegetables (Elizaquível, Sánchez, \& Aznar, 2012; Elizaquível, Sánchez, Selma, et al., 2012; Liu \& Mustapha, 2014; Moyne et al., 2013). However, the target genes used in the cited studies were uidA, RfbE, and IpfA, none of which are specific for pathogenic strains. Therefore, the aim of this study was to evaluate PMA-qPCR to detect and quantify viable STEC cells in beef burgers.

\section{2 | MATERIALS AND METHODS}

\section{1 | Experimental design}

This study included a qPCR validation in order to determine the assay performance characteristics according to the MIQE guidelines (Bustin et al., 2009). After that, five assays were performed. Each assay was carried out twice with three replicates per test.

\subsection{1 | Target gene selection}

Primers and probes for the detection of $s t x_{1}$ and $s t x_{2}$ genes were used (ISO 13136:2012). The fragment that led to the best qPCR performance, based on analytical sensitivity (Limit of detection: LOD), qPCR efficiency, linear dynamic range, and precision, was selected for further assays.

\subsection{2 | Assay 1}

Minimal concentration of PMA to inhibit non-viable cell signal. The samples included in the present assay were cells suspensions of nonviable STEC with three different concentrations (4, 5, and 6 log cfu/ $\mathrm{ml}$ ). Each concentration was treated with three different concentrations of $\mathrm{PMA}(0,50$, and $100 \mu \mathrm{M})$.

\subsection{3 | Assay 2}

Potential interference of PMA on the amplification of different concentrations of viable cells. The samples included in this assay were two sets of serial 10 -fold dilutions of viable STEC cell suspension $(3,4,5$, and $6 \log \mathrm{cfu} / \mathrm{ml})$. One set was treated with $100 \mu \mathrm{M}$ of PMA while the other one was not.

\subsection{4 | Assay 3}

PMA effectiveness to distinguish among different logarithmic orders of viable cells, in the presence of a high concentration of non-viable cells, in cell suspensions. The samples included in this assay were two sets of serial 10-fold dilutions of cell suspensions of viable STEC (1-7 $\log \mathrm{cfu} / \mathrm{ml}$ ), mixed with $5 \log \mathrm{cfu} / \mathrm{ml}$ cell suspension of non-viable STEC. One set was treated with $100 \mu \mathrm{M}$ of PMA while the other one was not.

\subsubsection{Assay 4}

PMA effectiveness to distinguish among different logarithmic orders of viable cells in the presence of a high concentration of non-viable cells, in beef burgers homogenates. The samples were two sets of beef burgers homogenates inoculated with a serial of 10 -fold dilutions of cell suspensions of viable STEC (1-7 log cfu/ml) mixed with 5 $\log \mathrm{cfu} / \mathrm{ml}$ cell suspension of non-viable STEC. One set was treated with $100 \mu \mathrm{M}$ of PMA while the other one was not. The aim was to determine if the food matrix had any effect in PMA effectiveness.

\subsection{6 | Assay 5}

PMA effectiveness to distinguish among viable and non-viable cells within the same logarithmic order of bacterial cells in beef burgers homogenates. The samples of this assay were two sets of beef burger homogenates inoculated with three mixtures of viable and non-viable STEC cells in ratios of 25:75, 50:50, and 75:25. One set was treated with PMA while the other one was not.

\section{2 | Preparation of viable cells}

The STEC strain used in this study was EDL 933. The culture was kept at $-80^{\circ} \mathrm{C}$ until subcultures were prepared by inoculating a test tube containing $10 \mathrm{ml}$ of tryptic soy broth (TSB, Biokar, France) with a single colony growth in MacConkey agar (MAC, Biokar, France), and incubated at $37^{\circ} \mathrm{C}$ overnight. Cells were harvested by centrifugation at $12,000 \mathrm{~g}$ for $5 \mathrm{~min}$ at room temperature (Centrifuge 5417C, Eppendorf, Germany) and the pellets were washed twice with phosphate-buffered saline solution (PBS, pH 7.2, Oxoid, UK). Cell suspensions were serial diluted to obtain final concentrations of 
$8,7,6,5,4,3,2$, and $1 \log \mathrm{cfu} / \mathrm{ml}$. STEC counts were performed in triplicate in $\mathrm{MAC}$ agar after incubation at $37^{\circ} \mathrm{C}$ for $24 \mathrm{hr}$.

\section{3 | Preparation of non-viable cells}

To obtain non-viable cells, an aliquot of $8 \mathrm{log} \mathrm{cfu} / \mathrm{ml}$ inoculum was treated at $95^{\circ} \mathrm{C}$ for $10 \mathrm{~min}$ in a dry heat plate. Cell viability was verified by plate count in tryptone soy agar (TSA, Biokar, France). Heat inactivated cells suspensions were serial diluted to obtain final concentrations of 6,5 , and $4 \log \mathrm{cfu} / \mathrm{ml}$.

\subsection{Beef burger preparation}

Beef burgers were formulated with $70 \%$ of ground meat, $20 \%$ of fat, $2 \%$ of $\mathrm{NaCl}$ (Dos Anclas, Argentina), and $0.25 \%$ of sodium tripolyphosphate (Prayphos, Argentina) and $7.75 \%$ of water. Meat was purchased at a retail store, minced, and then, beef burgers prepared following Szerman et al. (2019) methodology. Each batch was weighed, vacuum packed, and then frozen at $-20^{\circ} \mathrm{C}$ until further analysis.

\section{5 | Homogenates preparation}

Each beef burger was transferred into sterile stomacher bags and $90 \mathrm{ml}$ of $0.1 \%$ peptone water were added (PW, Biokar, France). Immediately after, samples were stomached (easy Mix, AES, France) for $60 \mathrm{~s}$ and kept in refrigeration conditions until analysis were performed.

\section{6 | Sample inoculation}

For assays 3 and 4, aliquots of $10 \mathrm{ml}$ of beef burger homogenates were inoculated with $100 \mu$ of viable and/or non-viable STEC cell suspensions. For assay 5 samples were inoculated with 25 , 50 , or $75 \mu \mathrm{l}$ of STEC cell suspensions, depending on the corresponding viable: non-viable ratio.

\section{7 | PMA treatment}

PMA (PMAxx, Biotium Inc., CA, USA) was diluted in DEPC water (UltraPure, Invitrogen, CA, USA) and stored in the dark at $-20^{\circ} \mathrm{C}$ as a $5 \mathrm{mM}$ working solution. The treatment with PMA was performed according to the manufacturer's instructions. Briefly, an aliquot of PMA $5 \mathrm{mM}$ and PMA enhancer $5 \mathrm{X}$ were added to $400 \mu \mathrm{l}$ of sample in order to achieve a final PMA concentration of $100 \mu \mathrm{M}$. After incubation at room temperature in the dark for 30 min with manual agitation, samples were exposed to photoactivation with a blue LED lamp (PhAST Blue, GenlUL, Spain) for $15 \mathrm{~min}$. After light exposure, the excess of PMA was removed by centrifugation at 8,000g for $10 \mathrm{~min}$ (Centrifuge 5417C, Eppendorf, Germany).

\section{8 | DNA extraction}

Genomic DNA extraction was carried out using DNeasy Blood and Tissue kit (Qiagen, Germany) following manufacturer's instructions for Gram negative bacterial DNA. The incubation time with proteinase $\mathrm{K}$ was of $1 \mathrm{hr}$.

\section{9 | Real-time PCR}

Real-time PCR was performed using an Applied Biosystems One Step Plus equipment (Thermo Fisher Scientific, USA). Primers and probes are described in the ISO 13136:2012 method (ISO 13136:2012, 2012) to detect $s t x_{1}$ and $s t x_{2}$ genes. A final reaction volume of $20 \mu \mathrm{l}$ was used, containing $10 \mu \mathrm{l}$ of $2 \mathrm{X}$ iTaq Universal Probes Supermix PCR master Mix (Bio-Rad, USA); $1 \mu \mathrm{M}$ of each primer, $0.2 \mu \mathrm{M}$ of probe, and $2 \mu$ l of DNA template.

The sequences of primers and probes were as follows: primer forward 5' TTTGTYACTGTSACAGCWGAAGCYT 3'; primer reverse 5' CCCCAGTTCARWGTRAGRTCMACRTC 3' and probes 5' FAM-TCGTCAGGCACTGTCTGAAACTGCTCC-BHQ1 3' for stx fragment and 5' HEX-CTGGATGATCTCAGTGGGCGTTCTTATGTAABHQ1 $3^{\prime}$ for $s t x_{1}$ fragment. The thermal cycling parameters were: $95^{\circ} \mathrm{C}$ for $10 \mathrm{~min}$, and then, 40 cycles at $95^{\circ} \mathrm{C}$ for $10 \mathrm{~s}, 55^{\circ} \mathrm{C}$ for $5 \mathrm{~s}$, $72^{\circ} \mathrm{C}$ for $15 \mathrm{~s}$, and $40^{\circ} \mathrm{C}$ for $30 \mathrm{~s}$ (Perelle et al., 2004).

\subsection{0 | Standard curve}

An overnight inoculum of STEC EDL 933 was divided in two aliquots. One of them was serial diluted and plated in triplicate over the surface of agar MAC and incubated at $37^{\circ} \mathrm{C}$ for $24 \mathrm{hr}$ in order to determine its concentration in $\mathrm{cfu} / \mathrm{ml}$ while the other one was used for DNA extraction as previously described. The DNA template obtained was fivefold diluted to obtain the standard curve points, ranging from $8.9 \mathrm{log} \mathrm{cfu} / \mathrm{ml}$ to $2.6 \mathrm{log} \mathrm{cfu} / \mathrm{ml}$. Each point was run 20 times in five different days to calculate the qPCR limit of detection (LOD), repeatability, linear dynamic range, and efficiency (Bustin et al., 2009). For LOD determination probit regression model was performed with a 95\% confidence interval (Kralik \& Ricchi, 2017), setting the limit at the lowest concentration of cfu/ml at which $95 \%$ of positive samples were detected. The repeatability (intra-assay variation) of the qPCR assays was calculated as the standard deviation of replicate samples within the standard curves. Limit of quantification (LOQ) was determined as the lowest concentration within the linear range of the standard curve (Kragh et al., 2020). Specificity was not determined since primers and hydrolysis probes used were from the ISO 13136:2012, and were only to detect STEC-specific genes. 


\subsection{1 | Statistical analysis}

The $\mathrm{Cq}$ values obtained from the different assays were analyzed using ANOVA and either the t-Student test or the Thamane test, depending on the variance analysis (Levene test). For all qPCR data a $p$ value $<0.05$ was considered statistically significant. The SPSS software package, version 21 (SPSS Inc., Chicago, III., U.S.A.) was used. The curve fitting, characterization of the qPCR and correlation analysis were performed using GraphPad Prism 6.0 software (San Diego, California, USA). All statistical analyses were carried out at a 95\% level of confidence.

\section{3 | RESULTS AND DISCUSSION}

\section{1 | qPCR validation}

Standard curves for $s t x_{1}$ and $s t x_{2}$ genes had similar slopes $(-3,298$ and $-3,364$, respectively) but the LOD for $s t x_{2}$ was lower (3.27 log $\mathrm{cfu} / \mathrm{ml})$ than the one for $\operatorname{stx}_{1}(4.26 \mathrm{cfu} / \mathrm{ml})$. For that matter, stx $x_{2}$ was used as the targeted gene for the following PMA-qPCR assays. The fact that this type of Shiga toxin is associated with the most severe illness also supports the use of the $s x_{2}$ gene for to detection and quantification of viable STEC cells in beef burgers (Guth et al., 2010).

As to the limit of quantification (LOQ) for qPCR that detected $s t x_{2}$ gene was of $3.33 \log \mathrm{cfu} / \mathrm{ml}$, corresponding to a $\mathrm{Cq}$ value of 35.52 . Samples with $\mathrm{Cq}$ values higher than that were considered negative. Linear dynamic range was between 8.92 and $3.33 \mathrm{log}$ cfu/ml. Efficiency values from the different standard curves were always between the acceptable limits of $90 \%-105 \%$ (Kralik \& Ricchi, 2017), with a mean of $98 \pm 2 \%$ and $R^{2}=0,97$. Among all assays performed on different days, no significant differences were found $(p<.05)$. Therefore, repeatability (intra-assay variation) is shown in Figure 1 as standard deviation in each point of the standard curve, for a $n=20$.

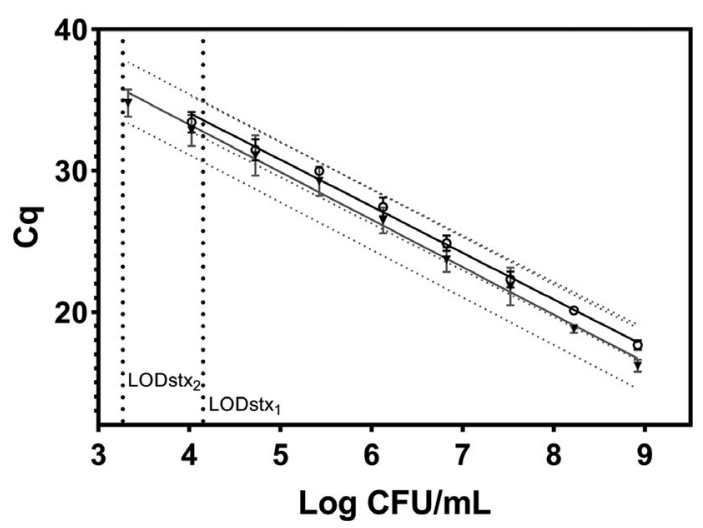

FIGURE 1 Standard curves for stx $_{1}$ (circles) and stx ${ }_{2}$ (triangles). Points represent an average of replicates and the bars correspond to the standard deviation $(n=20)$. LOD for both genes are represented in the figure as dotted vertical lines (LOD $=3.27$ for $s t x_{2}$ gene and LOD $=4.26$ for $s t x_{1}$ gene)

\subsection{Assay 1. Minimal concentration of PMA to inhibit non-viable cell signal}

As expected, the samples with non-viable STEC cells that were not treated with PMA were positive for $s t x_{2}$ gene with $\mathrm{Cq}$ values of 21.82, 25.58, and 31.12 for concentrations 6, 5, and $4 \log \mathrm{cfu} / \mathrm{ml}$, respectively. After a treatment with $50 \mu \mathrm{M}$ of PMA, the non-viable STEC samples were positive for $s x_{2}$ gene but with higher $C q$ values than the untreated samples. For the latter, the $\mathrm{Cq}$ values were as follows: 28.32, 29.71, and 33.38 for concentrations 6, 5, and 4 log $\mathrm{cfu} / \mathrm{ml}$, respectively. After the treatment with $100 \mu \mathrm{M}$ of PMA, the samples of $6 \mathrm{log} \mathrm{cfu} / \mathrm{ml}$ of non-viable STEC were positive for $s x_{2}$ gene with a Cq value of 32.76 while the samples of 5 and $4 \log \mathrm{cfu} / \mathrm{ml}$, the $s t x_{2}$ gene was undetectable (Table 1).

Based on these results, $50 \mu \mathrm{M}$ of PMA was not enough to inhibit the non-viable STEC signal, regardless of the concentrations analyzed. As to $100 \mu \mathrm{M}$ of PMA, it was able to inhibit 4 and 5 log $\mathrm{cfu} / \mathrm{ml}$, but not $6 \mathrm{log} \mathrm{cfu} / \mathrm{ml}$ of non-viable STEC cells. Similar results were reported by other authors (Li \& Chen, 2013; Liu et al., 2014). $\mathrm{Li}$ and Chen (2013) demonstrated that $50 \mu \mathrm{M}$ of PMA treatment was enough to inhibit the DNA amplification up to $4 \mathrm{log} \mathrm{cfu} / \mathrm{ml}$ nonviable Salmonella spp. in cell culture, whereas from $5 \mathrm{log} \mathrm{cfu} / \mathrm{ml}$ upward the signal was detected. Liu et al. (2014) showed that both, 50 and $100 \mu \mathrm{M}$ of PMA treatments completely inhibited qPCR signal up to $5 \mathrm{log} \mathrm{cfu} / \mathrm{ml}$ of non-viable E. coli O157:H7 cells in cell culture, whereas from $6 \mathrm{log} \mathrm{cfu} / \mathrm{ml}$ upward the signal was detected. The amplified gene used in the latter was the wzx gene. Laidlaw et al. (2019) used $100 \mu \mathrm{M}$ of PMA as the most suitable treatment to inhibit DNA amplification from dead E. coli $\mathrm{O} 157$ cells from beef, which agree with our work. However, these authors did not inform if the nonviable cell concentration was assessed. It is well known that at higher concentrations of cells, the turbidity of the samples increases. Cited authors suggested that turbidity, from the matrix or from cells, may affect PMA efficiency to bind DNA (Fu et al., 2020). The treatment of $100 \mu \mathrm{M}$ of PMA was selected for further analysis as effectively inhibits the real-time PCR signal of non-viable STEC cells, with the caveat that the final cell concentration of non-viable cells should not exceed $5 \mathrm{log} \mathrm{cfu} / \mathrm{ml}$. As Han et al. (2020) stated, differences in optimal PMA concentrations reported in literature may be due to the sensitivity of membranes from different bacterial strains, incubation times, and also type and power of light used in photoactivation steps. These authors obtained s successful qPCR signal inactivation after treating 6 log cfu/ml of non-viable cells of E. coli O157:H7 with $10 \mu \mathrm{M}$ of PMA in inoculated fresh produce samples.

\section{3 | Assay 2. Potential interference of PMA on the amplification of different concentrations of viable cells}

The samples included in this assay were two sets of serial 10-fold dilutions of cell suspensions of viable $\operatorname{STEC~}(3,4,5$, and $6 \log \mathrm{cfu} / \mathrm{ml})$. One set was treated with $100 \mu \mathrm{M}$ of PMA while the other set was 
TABLE 1 Minimal concentration of PMA to inhibit non-viable cell qPCR signal

\begin{tabular}{llll}
$\begin{array}{l}\text { Non-viable cell concentration } \\
(\log \mathrm{cfu} / \mathrm{ml})\end{array}$ & Without PMA & $50 \mu \mathrm{M}$ PMA & $100 \mu \mathrm{M}$ PMA \\
\hline 6 & $21.8 \pm 0.2^{\mathrm{c}}$ & $28.3 \pm 0.1^{\mathrm{c}}$ & $32.8 \pm 0.08^{\mathrm{a}}$ \\
\hline 5 & $25.6 \pm 0.3^{\mathrm{b}}$ & $29.7 \pm 0.03^{\mathrm{b}}$ & Undetectable \\
\hline 4 & $31.1 \pm 0.3^{\mathrm{a}}$ & $33.4 \pm 0.2^{\mathrm{a}}$ & Undetectable \\
\hline
\end{tabular}

Note: $\mathrm{Cq}$ values from different samples with their respective standard deviation are shown. Different letters correspond to significative differences between values. not. The $\mathrm{Cq}$ values of samples with PMA compared to the $\mathrm{Cq}$ values of samples without PMA were not different among themselves ( $p$ value $>0.05$ ) (Figure 2). As expected, Cq values decreased as the viable cell concentration increased, regardless of the PMA treatment $(p<.05)$. This result demonstrated that PMA had no influence on the QPCR signal of viable cells, indistinctly of the cell concentration analyzed. Similar results were reported by Moyne et al. (2013) who showed that $40 \mu \mathrm{M}$ of PMA did not interfere with DNA amplification of $7.5 \log$ cfu of E. coli O157:H7 viable cells on lettuce samples. Also, Liu and Mustapha (2014) described that $100 \mu \mathrm{M}$ of PMA had no effect on DNA amplification of $8 \mathrm{log} \mathrm{cfu} / \mathrm{ml}$ of viable $\mathrm{E}$ coli $\mathrm{O} 157: \mathrm{H7}$ cells in culture. Fu et al. (2020) treated agricultural soil samples with $25,50,75$, and $100 \mu \mathrm{M}$ of PMA to assess if the dye has influence on E. coli O157: $\mathrm{H} 7$ viable cells inoculated (5 log cfu/ml). These authors concluded that no significant difference between $\mathrm{Cq}$ values was obtained after PMA-qPCR, therefore, PMA did not affect viable cells in this type of samples.

\subsection{Assay 3. PMA effectiveness to distinguish among different logarithmic orders of viable cells in presence of a high concentration of non-viable cells in bacterial suspensions}

The samples included in this assay were two sets of serial 10 -fold dilutions of cell suspensions of viable STEC (1-7 log cfu/ml), mixed with $5 \mathrm{log} c f u / m l$ cell suspension of non-viable STEC. One set was

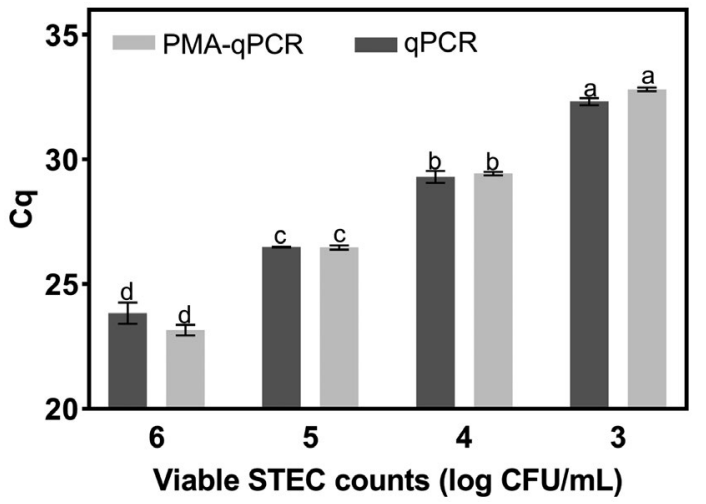

FIGURE 2 Potential interference of PMA on the amplification of different concentrations of viable cells. Note: Different letters mean significant differences between values $(p<.05)$. Bars are averages of replicates $(n=6)$ and error bars indicate standard deviation treated with $100 \mu \mathrm{M}$ of PMA while the other one was not. Without PMA treatment, no significant differences $(p>.05)$ were observed among the $\mathrm{Cq}$ values of samples with $1,2,3$, and $4 \mathrm{log} \mathrm{cfu} / \mathrm{ml}$ of viable cells, while significant differences $(p<.05)$ were registered among $\mathrm{Cq}$ values of samples with 5,6 , and $7 \mathrm{log} \mathrm{cfu} / \mathrm{ml}$ of viable cells (Figure 3). These differences were expected, as the number of viable STEC was higher than the number of non-viable STEC in the latter samples. In samples with PMA treatment, positive signals were recorded from $2 \mathrm{log} \mathrm{cfu} / \mathrm{ml}$ of viable cells upward. Significant differences $(p<.05)$ among the Cq values of samples with 3, 4, 5, 6 , and $7 \mathrm{log} \mathrm{cfu} / \mathrm{ml}$ of viable cells were recorded. As viable bacterial concentration increased, Cq values decreased (Figure 3). Based on these results it was concluded that, under the experimental conditions evaluated, PMA effectively distinguished among 3 to 7 log $\mathrm{cfu} / \mathrm{ml}$ of viable cells in the presence of a high concentration of non-viable cells. These results were consistent with the LOD previously calculated for qPCR. Similar results were reported by Liu and Mustapha (2014), who evaluated the effectiveness of $25 \mu \mathrm{M}$ PMA to differentiate DNA from viable and non-viable E. coli O157:H7 cells in culture. For that purpose, cited authors made mixtures containing $6 \mathrm{log} \mathrm{cfu} / \mathrm{ml}$ of non-viable cells of $\mathrm{E}$. coli $\mathrm{O} 157: \mathrm{H} 7$ in combination with viable cells ranging from 1 to $8 \mathrm{log} \mathrm{cfu} / \mathrm{ml}$. Under the conditions evaluated, these authors achieved a detection range of 2 to 8 log $\mathrm{cfu} / \mathrm{ml}$ which was larger than ours. This could be due to differences in the experimental conditions used in each of the assays as well as the light source for the photo activation process.

\section{5 | Assay 4. PMA effectiveness to distinguish among different logarithmic orders of viable cells in presence of a high concentration of non-viable cells in beef burgers homogenates}

This assay was carried out as described for assay 3 with the difference that cells were suspended in beef burger homogenates. Results showed that without PMA treatment no significant differences ( $p>$.05) were observed among the Cq values from samples with 2,3 , and $4 \log \mathrm{cfu} / \mathrm{ml}$ of viable cells, while significant differences were observed among Cq values of samples with 5, 6, and 7 log $\mathrm{cfu} / \mathrm{ml}$ of viable cells. As it was explained before, these differences were expected as the number of viable STEC was higher than the number of non-viable STEC in the last three samples. In those inoculated homogenates with PMA treatment, $\mathrm{Cq}$ values decreased as viable bacterial concentration increased (Figure 4). This behavior 


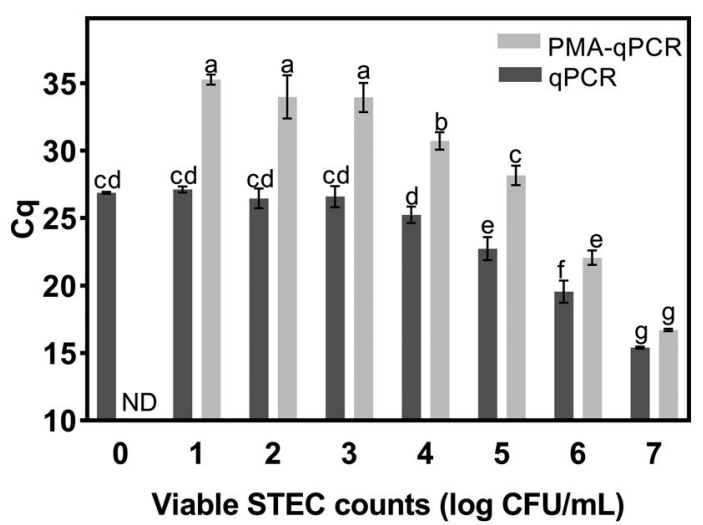

FIGURE 3 PMA effectiveness to distinguish among different logarithmic orders of viable cells in presence of a high concentration of non-viable cells in bacterial suspensions. Values on $x$ axis correspond to viable cells concentration. Sample with 0 log of viable cells (only non-viable) and treated with PMA was undetermined by qPCR (ND = Not determined). Note: Different letters mean significant differences between values $(p<.05)$. Bars are averages of replicates $(n=6)$ and error bars indicate standard deviation

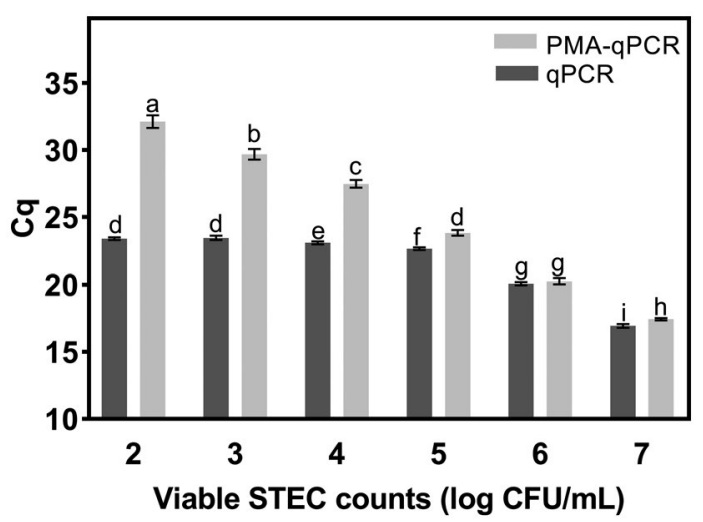

FIGURE 4 PMA effectiveness to distinguish among different logarithmic orders of viable cells in presence of a high concentration of non-viable cells in beef burgers homogenates. Values on $x$ axis correspond to viable cells concentration. Different letters mean significant differences between values $(p<.05)$

presents a linear tendency with a slope of 3.17 and Pearson coefficient of $R^{2}=0.99$, similar to the standard curve for qPCR previously described. Based on these results, food matrix had little effect on the amplification of different logarithmic orders of viable cells in presence of a high concentration of non-viable cells. In contrast, Liu and Mustapha (2014) reported that in ground beef samples the detection range was of 5 to $8 \log \mathrm{cfu} / \mathrm{g}$ instead of 1 to $8 \log \mathrm{cfu} /$ $\mathrm{ml}$ reported for cell suspensions, regardless of whether non-viable cells were present or not. Authors have suggested that this could be due to the high counts of background microflora and food matrix compounds that may inhibit PCR amplification or lead to a reduction in the amplification efficiency of PCR reactions. The differences with our results could be explained by the fact that the counts of background microflora were lower than 2 log cfu/g. Other source of variation could be the different DNA extraction methods. While we use a commercial column kit which guarantees clean templates with high yields, Liu and Mustapha (2014) used a reagent that does not have a purification step, therefore, cellular debris may be present in the DNA sample, affecting posterior qPCR. Our results were very promising for PMA-qPCR detection of mixed viable/non-viable STEC population in beef burgers.

\subsection{Assay 5. PMA effectiveness to distinguish among viable and non-viable cells within the same logarithmic order of bacterial cells in beef burger homogenates}

The samples of this assay were two sets of three mixtures of viable and non-viable STEC cells suspended in beef burger homogenates (25:75, 50:50, and 75:25). One set was treated with PMA while the other one was not. Without PMA treatment, Cq values for the three mixtures of viable and non-viable cells (25:75, 50:50, and 75:25) were 27.91, 27.45, and 27.32, respectively. With PMA treatment, $\mathrm{Cq}$ values increased proportionally as the fraction of viable bacteria decreased, as follows: 28.12, 28.81, and 29.57, respectively (Figure 5). These $\mathrm{Cq}$ values corresponded to concentrations extrapolated from the standard curve of 5.52, 5.32, and $5.10 \mathrm{log} \mathrm{cfu} / \mathrm{ml}$ which was consistent to the amount of viable bacteria inoculated in the homogenates.

These findings support the hypothesis that PMA is capable of distinguishing between viable and non-viable cells within the same logarithmic order of bacterial cell in beef burgers. These results were similar to those obtained by Liu et al. (2014), who evaluated PMAqPCR signal at different proportions of viable and non-viable $(30 \%$, $50 \%$, and $70 \%$ ) of E. coli O157:H7 cells in cell culture and reported higher $\mathrm{Cq}$ values as the amount of viable cells decreased.

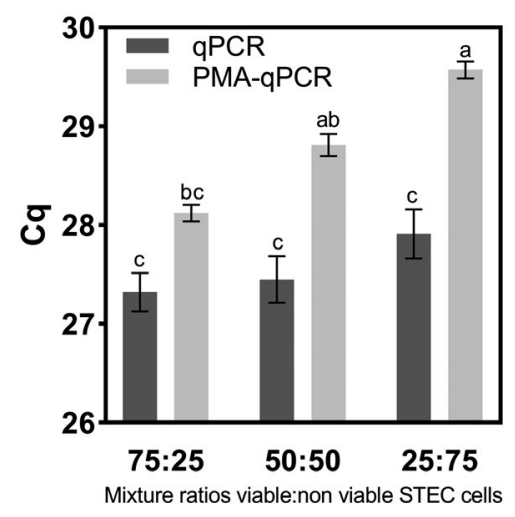

FIGURE 5 PMA effectiveness to distinguish among viable and non-viable cells within the same logarithmic order of bacterial cells in beef burger homogenates. Values on $x$ axis correspond to the ratios in which viable:non-viable cells were mixed. Different letters mean significant differences between values $(p<.05)$. Bars are averages of replicates $(n=6)$ and error bars indicate standard deviation 


\section{4 | CONCLUSIONS}

PMA real-time PCR that targeted the stx $x_{2}$ gene, was able to discriminate between viable and non-viable Shiga toxin-producing Escherichia coli in beef burger homogenates. This was demonstrated in samples with different logarithmic orders of viable cells, in presence of a high concentration of non-viable cells and in mixtures of viable and non-viable STEC cells within the same logarithmic order. This technique could be potentially used for the assessment of the effectiveness of antimicrobial treatments against STEC in beef burgers.

\section{ACKNOWLEDGMENTS}

We thank Cintia Natalia Gonzalez for technical assistance.

\section{CONFLICT OF INTEREST}

The authors have declared no conflicts of interest for this article.

\section{AUTHOR CONTRIBUTION}

María de los Ángeles Rey: investigation, conceptualization, writing-original draft, visualization. Mariana Cap: conceptualization, methodology, writing-original draft, review \& editing, visualization. Leonardo Cristian Favre: formal analysis-writing. Anabel Rodriguez Racca: formal analysis. María José Dus Santos: writing-review \& editing. Sergio R. Vaudagna: funding acquisition, project administration. Marina Mozgovoj: conceptualization, writing-review \& editing, methodology, visualization, project administration.

\section{ETHICAL APPROVAL}

This article does not contain any studies with human participants or animals performed by any of the authors.

\section{DATA AVAILABILITY STATEMENT}

The data that support the findings of this study are available from the corresponding author upon reasonable request.

\section{INFORMED CONSENT}

Informed consent not applicable.

\section{ORCID}

María de los Ángeles Rey (iD https://orcid.

org/0000-0003-3378-6436

Mariana Cap iD https://orcid.org/0000-0003-4898-710X

\section{REFERENCES}

Banihashemi, A., Dyke, M. I., \& Huck, P. M. (2012). Long-amplicon propidium monoazide-PCR enumeration assay to detect viable Campylobacter and Salmonella. Journal of Applied Microbiology, 113, 863-873. https://doi.org/10.1111/j.1365-2672.2012.05382.x

Bustin, S. A., Benes, V., Garson, J. A., Hellemans, J., Huggett, J., Kubista, M., Mueller, R., Nolan, T., Pfaffl, M. W., Shipley, G. L., Vandesompele, J., \& Wittwer, C. T. (2009). The MIQE guidelines: Minimum information for publication of quantitative real-time PCR experiments.
Clinical Chemistry, 55, 611-622. https://doi.org/10.1373/clinc hem.2008.112797

Centers for Disease Control and Prevention. (2019). https://www.cdc. gov/ecoli/2019/o103-04-19/index.html

Elizaquível, P., Sánchez, G., \& Aznar, R. (2012). Application of propidium monoazide quantitative PCR for selective detection of live Escherichia coli $\mathrm{O} 157: \mathrm{H} 7$ in vegetables after inactivation by essential oils. International Journal of Food Microbiology, 159, 115-121. https:// doi.org/10.1016/j.ijfoodmicro.2012.08.006

Elizaquível, P., Sánchez, G., Selma, M. V., \& Aznar, R. (2012). Application of propidium monoazide-qPCR to evaluate the ultrasonic inactivation of Escherichia coli $\mathrm{O} 157: \mathrm{H7}$ in fresh-cut vegetable wash water. Food Microbiology, 30, 316-320. https://doi.org/10.1016/ j.fm.2011.10.008

Fu, Y., Ye, Z., Jia, Y., Fan, J., Hashmi, M. Z., \& Shen, C. (2020). An Optimized method to assess viable Escherichia coli $\mathrm{O} 157: \mathrm{H} 7$ in agricultural soil using combined propidium monoazide staining and quantitative PCR. Frontiers in Microbiology, 11, 1-9. https://doi.org/10.3389/ fmicb.2020.01809

Guth, B. E. C., Prado, V., \&Rivas, M. (2010). Shiga toxin-producing Escherichia coli. In Pathogenic Escherichia coli in Latin America (65-83). Bentham Science Publishers.

Han, L., Wang, K., Ma, L., Delaquis, P., Bach, S., Feng, J., \& Lu, X. (2020). Viable but nonculturable Escherichia coli O157: $\mathrm{H7}$ and Salmonella enterica in fresh produce: Rapid determination by loop-mediated isothermal amplification coupled with a propidium monoazide treatment. Applied and Environmental Microbiology, 86(7), 1-13. https:// doi.org/10.1128/AEM.02566-19

ISO 13136:2012, I. (2012). Microbiology of food and animal feed - Realtime polymerase chain reaction (PCR)-based method for the detection of food-borne pathogens - Horizontal method for the detection of Shiga toxin-producing Escherichia coli (STEC) and the determination of O157.

Kragh, M. L., Thykier, M., \& Truelstrup Hansen, L. (2020). A longamplicon quantitative $\mathrm{PCR}$ assay with propidium monoazide to enumerate viable Listeria monocytogenes after heat and desiccation treatments. Food Microbiology, 86, 103310. https://doi.org/10.1016/ j.fm.2019.103310

Kralik, P., \& Ricchi, M. (2017). A basic guide to real time PCR in microbial diagnostics: Definitions, parameters, and everything. Frontiers in Microbiology, 8(108), 1-9. https://doi.org/10.3389/fmicb.2017.00108

Laidlaw, A. M., Gänzle, M. G., \& Yang, X. (2019). Comparative assessment of qPCR enumeration methods that discriminate between live and dead Escherichia coli 0157:H7 on beef. Food Microbiology, 79, 41-47. https://doi.org/10.1016/j.fm.2018.11.002

Li, B., \& Chen, J.-Q. (2013). Development of a sensitive and specific qPCR assay in conjunction with propidium monoazide for enhanced detection of live Salmonella spp. in food. BMC Microbiology, 13, 273. https://doi.org/10.1186/1471-2180-13-273

Liu, H., Niu, Y. D., Li, J., Stanford, K., \& McAllister, T. A. (2014). Rapid and accurate detection of bacteriophage activity against Escherichia coli O157:H7 by propidium monoazide real-time PCR. BioMed Research International, 2014, 1-9. https://doi.org/10.1155/2014/319351

Liu, Y., \& Mustapha, A. (2014). Detection of viable Escherichia coli O157:H7 in ground beef by propidium monoazide real-time PCR. International Journal of Food Microbiology, 170, 48-54. https://doi. org/10.1016/j.ijfoodmicro.2013.10.026

Liu, Y., Zhong, Q., Wang, J., \& Lei, S. (2018). Enumeration of Vibrio parahaemolyticus in VBNC state by PMA-combined real-time quantitative PCR coupled with confirmation of respiratory activity. Food Control, 91, 85-91. https://doi.org/10.1016/j.foodcont.2018.03.037

Moyne, A.-L., Harris, L. J., \& Marco, M. L. (2013). Assessments of total and viable Escherichia coli $0157: \mathrm{H7}$ on field and laboratory grown lettuce. PLoS One, 8, e70643. https://doi.org/10.1371/journal. pone.0070643 
Nocker, A., Cheung, C. Y., \& Camper, A. K. (2006). Comparison of propidium monoazide with ethidium monoazide for differentiation of live vs. dead bacteria by selective removal of DNA from dead cells. Journal of Microbiological Methods, 67, 310-320. https://doi.org/10.1016/ j.mimet.2006.04.015

Perelle, S., Dilasser, F., Grout, J., \& Fach, P. (2004). Detection by 5'-nuclease PCR of Shiga-toxin producing Escherichia coli O26, 055, 091, O103, 0111, 0113, O145 and 0157:H7, associated with the world's most frequent clinical cases. Molecular and Cellular Probes, 18, 185-192. https://doi.org/10.1016/j.mcp. 2003.12.004

Scariot, M. C., Venturelli, G. L., Prudêncio, E. S., \& Arisi, A. C. M. (2018). Quantification of Lactobacillus paracasei viable cells in probiotic yoghurt by propidium monoazide combined with quantitative PCR. International Journal of Food Microbiology, 264, 1-7. https://doi. org/10.1016/j.ijfoodmicro.2017.10.021

Szerman, N., Ferrari, R., Sancho, A. M., \& Vaudagna, S. (2019). Response surface methodology study on the effects of sodium chloride and sodium tripolyphosphate concentrations, pressure level and holding time on beef patties properties. LWT, 109, 93-100. https://doi. org/10.1016/j.lwt.2019.04.001
Taskin, B., Gozen, A. G., \& Duran, M. (2011). Selective quantification of viable Escherichia coli bacteria in biosolids by quantitative PCR with propidium monoazide modification. Applied and Environment Microbiology, 77, 4329-4335. https://doi.org/10.1128/aem.02895-10

Xing-long, X., Cong-cong, L., Yang, Q., Yi-gang, Y., \& Hui, W. (2013). Molecular monitoring of Escherichia coli 0157: $\mathrm{H} 7$ sterilization rate using qPCR and propidium monoazide treatment. Letters in Applied Microbiology, 56, 333-339. https://doi.org/10.1111/lam.12052

Zhong, J., \& Zhao,X. (2018). Detection of viable butnon-culturable Escherichia coli $\mathrm{O} 157: \mathrm{H7}$ by PCR in combination with propidium monoazide. 3. Biotech, 8, 28. https://doi.org/10.1007/s13205-017-1052-7

How to cite this article: Rey MDLÁ, Cap M, Favre LC, et al. Evaluation of PMA-qPCR methodology to detect and quantify viable Shiga toxin-producing Escherichia coli in beef burgers. J Food Process Preserv. 2021;00:e15338. https://doi.org/10.1111/jfpp.15338 